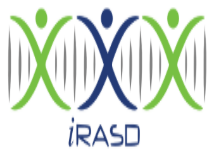

iRASD Journal of Management

Volume 3, Number 3, 2021, Pages 400 - 410

Journal Homepage:

https://journals.internationalrasd.org/index.php/jom $i$ RASD

JOURNAL OF MANAGEMENT

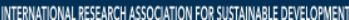

\title{
Information Technology Competencies: A Performance Booster for Organizations
}

Syed Zain ul Abdin ${ }^{1}$, Ali Junaid Khan ${ }^{2}$, Shahzad Ali Gill ${ }^{3}$, Tanveer Ahmed ${ }^{4}$

${ }^{1}$ Assistant Professor, Institute of Business, Management \& Administrative Sciences, The Islamia University of Bahawalpur, Pakistan. Email: zain.naqvi4824@gmail.com

${ }^{2}$ Institute of Business Management \& Administrative Sciences, The Islamia University of Bahawalpur, Pakistan. Email: Junaaidkhan@yahoo.com

${ }^{3}$ Assistant Professor, Department of Public Administration, The Islamia University of Bahawalpur, Pakistan. Email: shahzadaligill@gmail.com

${ }^{4}$ Department of Environmental Management, National College of Business Administration \& Economics, Lahore, Pakistan. Email: Ranatanveer786@gmail.com

ARTICLE INFO

Article History:

Received: $\quad$ November 05, 2021

Revised: December 29, 2021

Accepted: $\quad$ December 30, 2021

Available Online: December 31, 2021

\section{Keywords:}

IT competencies

Financial performance

Organizational performance

Pakistan

SmartPLS

\section{ABSTRACT}

The purpose of this study is to examine the influence of information technology competencies on financial performance, followed by organizational performance. The primary data collection technique was used to collect the data from 165 IT officers and top managers from Pakistan. Structural equation modelling was applied using Smart PLS 3 to examine the hypothesized model. The direct findings reveal that all three components of IT competencies are statistically significant in organizational performance. Among the three components, information technology infrastructure is the strongest predictor of organizational performance. Further, organizational performance is statistically significant in determining financial performance. There are no direct significant influences of IT competencies toward financial performance. Indirect results show that all three components of IT competencies are statistically significant. IT infrastructure is the strongest predictor of financial performance through organizational performance. Moreover, this study reveals that IT competencies are not merely sufficient to maintain financial performance. Additionally, the firm is also required to focus on complementary indicators such as innovation, quality, customer satisfaction, customer retention, and reduction of operating cost-which are generated by proper utilization of IT competencies.

(c) 2021 The Authors, Published by iRASD. This is an Open Access article under the Creative Common Attribution Non-Commercial 4.0

Corresponding Author's Email: Junaaidkhan@yahoo.com

\section{Introduction}

Previous studies have explored the relationship between information technology and the financial performance of firms (Kamssu, Reithel, \& Ziegelmayer, 2003; Shin, 2006). However, most researchers examine the direct relationship between information technology and financial performance (Bharadwaj, 2000; Sadeghimanesh \& Samadi, 2014), giving less consideration to the underlying process through which these relationships affect to fill this gap, this research examines the mediation process that advance describes these relationships. By investigating different mediation processes, we gain a better understanding of processes (Farooq, Payaud, Merunka, \& Valette-Florence, 2014). The mediation process provides better information that enhances the practical application of information technology toward the manufacturing firm. 
To the best of the authors' knowledge, this paper goes far from prior literature to investigate organizational performance as a mediation mechanism to measure the financial performance of manufacturing firms in relation to information technology. The Competencies model supports this mechanism that is proposed between information technology and firms' financial performance (Soto-Acosta, Popa, \& Martinez-Conesa, 2018). The information technology competencies model explains the relationship between information technology components and financial performance. It ascertains the firmrelated indicators that are subject to organizational performance. This study incorporates three components of information technology competencies, named IT-knowledge, operations, and infrastructure, and treats them independently to investigate their effects on organizational performance and, in turn, firms' financial performance. This study tests the components separately to help the top management deeply understand their IT competencies and organizational performance, which helps the firm strengthen its financial position. Various studies found the relationship between IT interventions and increased organizational performance (Batool, Gill, Javaid, \& Khan, 2021). This study contributes to the literature of financial management by introducing the information technology competencies model as the perceptual antecedent of financial performance.

In the second section, the theoretical model and hypotheses development were discussed. In the third section, the method follows with the data analysis and results. In the last, discussion follows with limitation and conclusion.

\section{Research Model and Hypotheses Development 2.1. IT-Competencies and Organizational Performance}

In the present decade, several researchers investigate information technology influences organizational performance (Durmuşoğlu \& Barczak, 2011; Jensen, 2007). The information technology revolution changes the way of doing business (Batool et al., 2021; Jud, Winkler, \& Sirmans, 2002). Now a day, Information technology is working as a backbone for every kind of business and basic need to survive in a market. Therefore, Information technology may have major roles to maintain organizational performance. Information technology competence consists of three elements that may influence organizational performance. Information technology-knowledge is a combination of information in terms of context, experience, and interpretation (Davenport, De Long, \& Beers, 1998). Technical knowledge is a set of rules and techniques used to achieve the desired goal. Information technology knowledge relies on know-how about new technology such as computer-based systems. In essence, Information technology knowledge is conceptualized as technical knowledge which can be collected from the market. Information technology knowledge determines the skills to use market knowledge and create new knowledge and innovation. Next, to achieve the desired goal information technology operation make a set of activities to gain the desired objective (Mitcham \& Mackey, 1983).

IT operation is the subset of IT knowledge because the implantation of technical knowledge is based on IT operation. The value of one competency is enhanced by the presence of another competency (Kozlenkova, Samaha, \& Palmatier, 2014). Therefore, the value of information technology is enhanced when the firm used it to improve knowledge for their customer, the market, and other stakeholders that may influence organizational performance (Bhatti, Farhan, Ahmad, \& Sharif, 2019). The enhancement of information technology knowledge is important to create a sustainable competitive advantage in the marketplace (Dong, Karhade, Rai, \& Xu, 2021; Noshad, Amjad, Shafiq, \& Gillani, 2019). Therefore, IT knowledge positively relates to the organizational performance of the firm. Literature documented the role of information technology as an imperative intangible resource for the organization (Palacios-Marqués, Soto-Acosta, \& Merigó, 2015).

IT operation enables the firm to use information technology to manage the market, customer information, new product launching, and product quality and customer retention (Jianjun et al., 2021). In sense, IT operation requires technical skills such as decisionmaking, effective problem solving, and managerial skills. IT operation is also assumed as an appearance of information technology knowledge in that the execution of IT-knowledge outcomes in IT operations (Tippins \& Sohi, 2003). In the existence of higher information technology knowledge, these skills may become enhanced. Information technology 
operations are the degree to which an organization employs information technology to accomplish market and client information (Shair et al., 2021; Wu, Straub, \& Liang, 2015). IT operations consist of techniques that are used to achieve a particular goal (Marsdenia, 2017). Therefore, this study operationalized the IT operations to the extent of collecting market information about their customer and competitors. Hence, IT operations are positively related to the organizational performance of the firm. IT-operation outcome linked to the achievement of market outcomes (Tatikonda \& Montoya-Weiss, 2001). Therefore, IT operation link with organizational performance.

Furthermore, IT infrastructure enables the employees to collect and retrieve the actual information about the market. IT infrastructure eases the processing and delivery of information that makes the firm more valuable in the market. Information was gathered from the market regarding three components of IT (Slater \& Narver, 1995). In essence, all information is based on the market. IT infrastructure enables to enhance the organizational performance. Therefore, IT infrastructure positively influences organizational performance. All three components of IT competency describe the firms' ability to use the IT techniques, skills, and knowledge that are essential to maximizing organizational performance. Based on these conceptual arguments, the first hypothesis is as follows:

Hypothesis 1: IT competencies have a positive effect on organizational performance.

\subsection{Mediating Role of Organizational Performance}

These studies show a strong relationship between IT competencies and financial performance (Tam, 1998; Whitten, Ellis, \& Casey, 2002). In contrast, some studies develop a link between IT competencies and organizational performance (Pérez-López \& Alegre, 2012). In a competitive environment, Information technology provides mechanisms to be successful in the market (Pérez-López \& Alegre, 2012; Rasool, Asghar, Gill, \& Khan, 2021). Nowadays, information technology has exceeded the perfunctory functions of recording and processing data. Information technology is known to provide a lasting competitive advantage, making the overall organizational structure more robust (Powell \& Dent-Micallef, 1997). Organizations must assess their information technology competencies regularly to retain their competitive advantage in the market (Peppard, Lambert, \& Edwards, 2000). Information technologies help organizations to achieve competitive advantage in terms of innovation, quality, customer satisfaction, customer retention, employees commitment (Junaid, Bashir, Nasim, \& Ahmad, 2021) and reduction of operating cost; and in turn, use these competitive advantages to increase organizational performance (Khan, Tufail, \& Ali, 2021) that ultimately leads towards better financial performance.

The stakeholders of organizations aren't only concerned about how the firm is maintaining financial performances; rather they also deliberate on elongating their competitive advantages. Investors are more interested in firms that maintain a better focus on innovation, quality and customer satisfaction, customer retention, and reduction of operating costs (Chien et al., 2021; Rasool et al., 2021).

Hypothesis 2: Organizational performance positively influences financial performance.

Most firms invest in information technology intending to improve their financial performance. Firms need information technologies so that they can maintain their competitive position in the market to achieve desired financial performance (Lai, Zhao, \& Wang, 2006). Information technology is essential just to keep up with market changes. One explanation is that Information technology is also used by almost all stakeholders, they used it to find the lower-cost product or different suppliers. IT-competencies help to create improvements that are difficult to emulate for competitors (Batool et al., 2021; Liang, You, \& Liu, 2010). Bharadwaj (2000) argues that firms that invest in IT competencies enjoy superior financial performance over their competitors. Information technology increase product quality, customer satisfaction, customer retention, innovation and reduce operating cost. Conversely, it is very challenging for firms to use those advantages as an economic benefit. Although information technology may provide better organizational performance, these advantages result in better financial performance. Therefore, almost all competitive 
firms invest in IT competencies to increase their financial performance followed by improved organizational performance.

Moreover, IT competencies have rapidly changed the way of conducting business. IT competencies increase the firm financial position (Shin, 2006). Tam (1998) found a mixed relationship between Information technology and financial performance. Consequently, there is some gap that governs the relationship between IT competency and firm performance. Therefore, taking into account 'organizational performance' as a mediator. Organizational performance may show a strong relationship between IT competencies and financial performance. Investment in IT competencies influences the market in a way to change the image of the firm in investors' perception. Therefore, organizational performance is the perceptional antecedent of financial performance. Firms increase their performance by investing in IT competencies (Tippins \& Sohi, 2003). There are many other antecedents of organizational performance like employee commitment, job satisfaction, training and adoptions of CSR initiative (Khan, Bhatti, Hussain, Ahmad, \& Iqbal, 2021) which are difficult to copy. Organizational investment in IT interventions can leads toward these antecedents that will leads toward the organizational and financial performance. Therefore, IT competencies influence financial performance in relation to organizational performance. Thus, we can conceptualize the following hypotheses:

Hypothesis 3: Organizational performance mediates the relationship between IT competencies and financial performance.

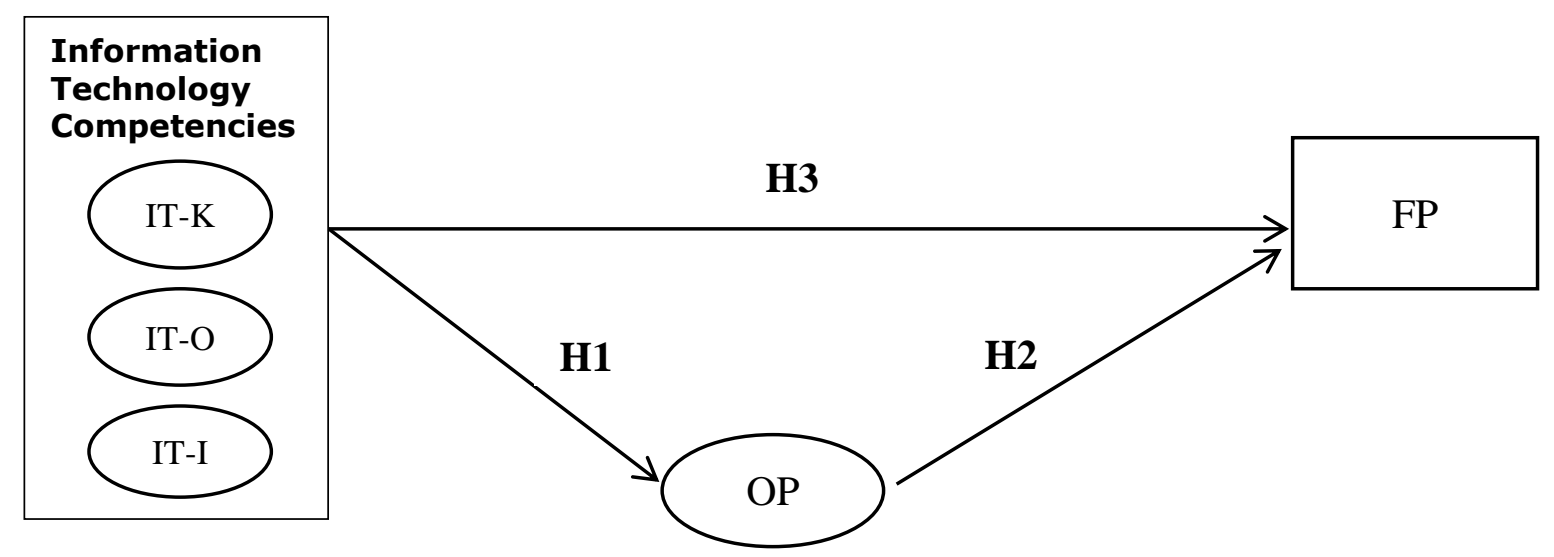

Figure.1: Hypothesized Model: IT-K represents Information technology Knowledge; IT-O represents Information technology Operation; IT-I represents Information infrastructure; OP represents Organizational performance; FP represents Financial Performance.

\section{Research Methodology \\ 3.1. Sample and Procedure}

This research used a quantitative approach using a survey technique to collect data on the five constructs that are proposed in the research model as shown in figure 1 . The self-completion survey is the best technique to address the research question that is proposed in this study. The survey is best because, it determines the true value of constructs and the strength of relationship among constructs (Newsted, Huff, \& Munro, 1998). As Newsted, Todd, and Zmud (1997) outlined that with the help of survey data on one question numbers or scales are gathered. Further, the most suitable analysis can be applied to these scales or numbers to analyze the postulate hypotheses and confirm the conceptualized research model. Multisource data will be collected from the IT manager and respective top management by using the survey method. First, top management was approached, and their informed consent was asked. After this, data was collected from IT managers/heads about IT knowledge, operation, and infrastructure by using a self-rated survey. After this, data related to organizational performance and firms' financial performance was collected from top managers by using a questionnaire. Therefore, the unit of analysis for the study is the top management and IT manager. The constructs related to IT competency fill by IT managers. To fill this part of the questionnaire, it was sent through email and face-to-face contact with the IT department of particular companies after getting 
permission from a higher authority. Organizational performance and the financial performance constructs are filled by top managers that are involved in the decision-making. Once the data were collected from the IT manager, it assigns one specific code and sends the second part of the questionnaires to the top manager of that particular firm. Hence, the researchers easily match and organize the data for further analysis. Totally 577 companies with 35 sectors listed on Pakistan Stock Exchange. This study targeted non-financial manufacturing companies. Thus, the Population is about 416 companies. From which 158 numbers of companies do not promote IT culture in their organization. Therefore, the final population is 248. The textile (spinning, weaving, and finishing) and cement industries' response were reasonable. Most of the other industries are also involved in the sample but the response rate is not reasonable. Researchers do not target a specific sector.

This study targets the companies that publish information technology-related information on their website since publically available information indicates that the companies are involved in the topical information technology competencies issue. Researchers contacted the targeted companies and sought their permission and support for data collection. The data were collected face-to-face, using a self-reporting questionnaire. Researchers personally handed over and email the questionnaire to the participants willing to participate in the research. Due to the lack of confidence of the respondents, a questionnaire was covered by a letter that provides information that their information will keep confidential. The questionnaire consists of some items that are confidential for an organization such as their innovation and new product launching. Therefore, to present the companies name is unethical considerations. Therefore, using this technique of sampling, each group within the research population retains an equal chance of being selected to be characterized in the sample size.

The study targeted all 248 companies but only collected data from 165 which are used for further analysis. To ensure reliability, pilot study and pretest have been measured using SPSS 22.0. In the pilot study, all the constructs achieve the minimum criteria that confirm the internal consistency of the research. In the pretest, the hot dock method is used to remove the missing values and make the sample more reasonable. Table 1 represents the descriptive statistics of the model such as mean, standard deviation, and correlation. The correlation table shows the understanding of all hypothesized and nonhypothesized relations among the concept.

\section{Table 1}

Descriptive Statistics: Mean, SD and Correlation

\begin{tabular}{|c|c|c|c|c|c|c|c|}
\hline Variables & Mean & SD & 1 & 2 & 3 & 4 & 5 \\
\hline IT-Knowledge & 3.589 & 0.948 & 1 & & & & \\
\hline IT-Operation & 3.427 & 0.819 & $.419 * *$ & 1 & & & \\
\hline IT-Infrastructure & 3.652 & 0.92 & $.484 * *$ & $.422 * *$ & 1 & & \\
\hline Organizational performance & 3.622 & 0.882 & $.481 * *$ & $.360 * *$ & $.482 * *$ & 1 & \\
\hline Firms' Financial Performance & 3.33 & 0.987 & $.470 * *$ & $.402 * *$ & $.347 * *$ & $.453^{* *}$ & 1 \\
\hline
\end{tabular}

\subsection{Measurement}

To measure IT competencies, we focused on three dimensions, IT knowledge, IT operation, and IT infrastructure as worked by (Tippins \& Sohi, 2003). Three items are reported to measure IT knowledge, four items to IT operation, and three items to IT infrastructure. Thus, the final measurement of IT competency consists of ten items. Furthermore, an organizational performance that is used as a mediator developed by the work of Zack, McKeen, and Singh (2009). The organizational performance consists of five items and financial performance of three items. Thus, the final version of questionnaires contained eighteen items to measure the structural relation of five latent constructs. Respondents were answered on five Likert scales from strongly disagree to strongly agree. All the part of the questionnaire used five-point Likert scales so technically there is no issue of data matching. Questionnaires data were entered into SPSS latest version 22 and converted into CSV to apply smart PLS 3.0. 


\section{Analysis}

Structural Equation Modeling (SEM) is considered the most prominent method to analyze the proposed model in the business and management field. There are two approaches to SEM that are used in the social sciences. First is CB-SEM that is established on covariance-based techniques. CB-SEM is used the AMOS to test the proposed model. The second is PLS-SEM that is the variance-based partial least square method. PLS path modeling was considered a soft modeling method because it does not impose major restrictive assumptions on the data, such as sample size and normality of data. The data for this study is not normally distributed and has a small sample size. Therefore, PLS-SEM is best to test the proposed model. Smart PLS 3.0 was used to examine the structural paths that are hypothesized. For their knowledge researchers apply the CB-SEM to confirm the results and check the robust evidence. The CB-SEM shows that it is not best suited that do not support the proposed hypotheses because it does not fulfill the particular assumption of the analysis. Linear regression was also not best suited for the proposed model because the process of mediation is involved in the model. Therefore, the best analysis for the data set is PLS-SEM.

\subsection{Data Analysis and Results}

Data analysis was analyzed on the one hundred and sixty-five usable questionnaires completed from the higher authority of manufacturing companies listed in the Pakistan stock exchange. The partial least square model was developed to test the collected data (Fig. 1). Three steps approach was used to measure the proposed path modeling. First, we confirmed the reliability and validity of all latent constructs followed by convergent and discriminant validity. After confirming the quality of measurement, the second step is to indicate the effect of each causal path. The core concern of this study is to examine the direct and indirect effect of IT competencies on organizational performance and financial performance. At last, we performed Baron and Kenny (1986) analysis to investigate the specific indirect effect of organizational performance.

\section{Table 2}

Outer Loading, Reliability, and Convergent Validity

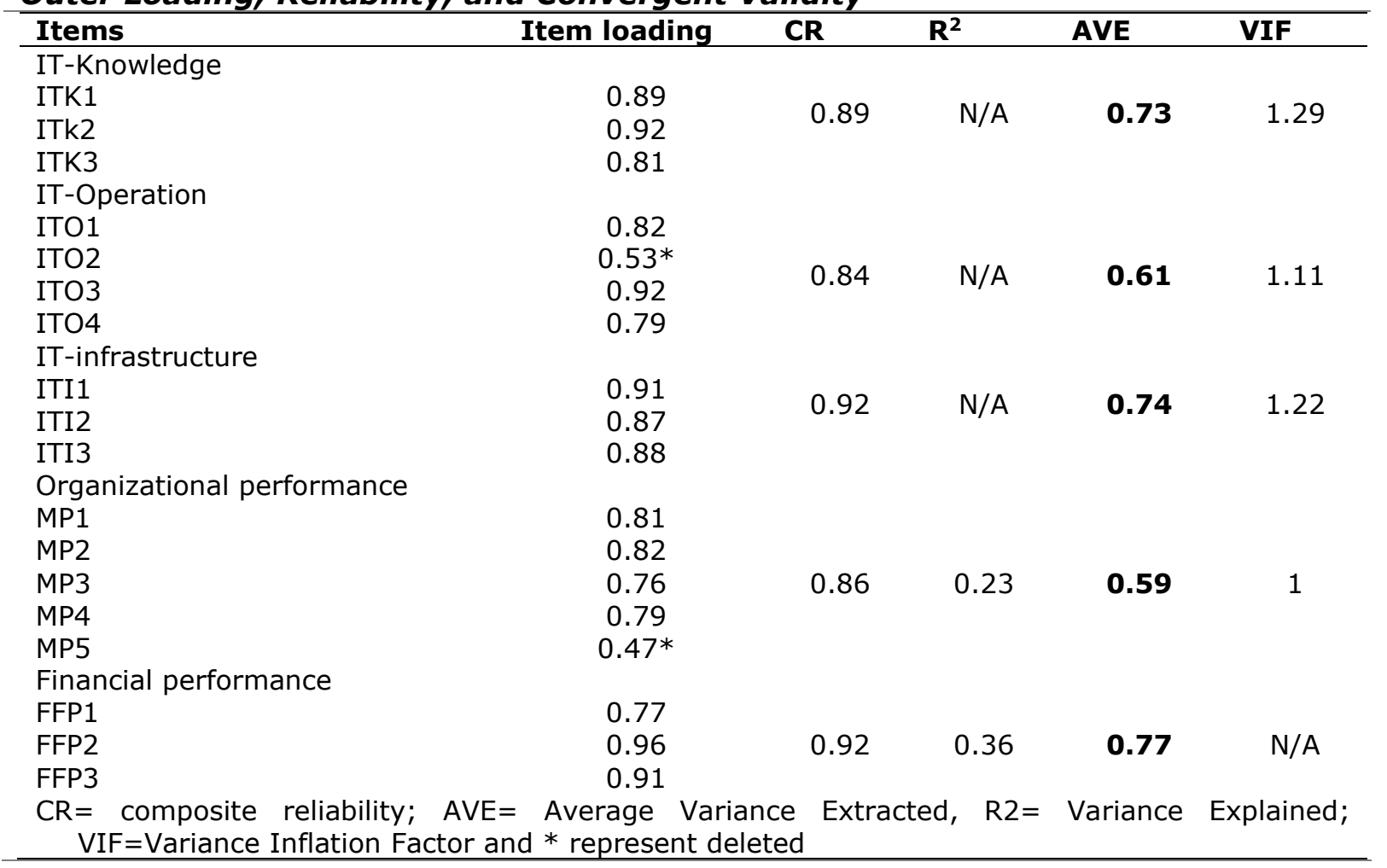

Internal consistency is confirmed by the value of composite reliability that should be greater than 0.7. Therefore, this study achieved the minimum criteria (Table 2). Further, the outer loading should be higher than 0.7 to confirm the reliability of the items. In this 
study, all latent constructs items achieved the minimum criteria except ITO2 from IToperation and MP4 from organizational performance (Table 2). As well as there is no Multicollinearity issue in collected data all VIF value is less than 5 . The convergent validity is achieved by following the standard of Fornell and Larcker (1981). The Average Variance Extracted (AVE) value should be higher than 0.5 . It indicates that $50 \%$ of variance due to the specified constructs. In this study, all constructs attained the minimum criteria (Table 3 ). Next, Discriminant validity is achieved if the square root of average variance extracted (AVE) is higher than the correlation of all other variables. Hence, discriminant validity is confirmed (Table 3 ). The predictive power of organizational performance is 0.331 that is moderate in the partial least square (Chin, 1998). Furthermore, according to Fornell and Larcker (1981), the $R^{2}$ should be a minimum of 0.1 . The variance explained for both dependents variables is shown in Table 2.

\section{Table 3}

Discriminant Validity

\begin{tabular}{|c|c|c|c|c|c|}
\hline Variables & 1 & 2 & 3 & 4 & 5 \\
\hline IT-Knowledge & 0.85 & & & & \\
\hline IT-Operation & 0.42 & 0.78 & & & \\
\hline IT-Infrastructure & 0.48 & 0.42 & 0.86 & & \\
\hline Organizational performance & 0.48 & 0.36 & 0.48 & 0.77 & \\
\hline Financial performance & 0.47 & 0.40 & 0.35 & 0.45 & 0.88 \\
\hline
\end{tabular}

*Squared root of AVE of all variables is displayed at diagonals

\subsection{Model Testing}

Model testing is conducted in two steps with PLS-SEM. In the first step, we examine the effect of all independent variables on the dependent variable (Table 4). All three predictor has a significant effect on organizational performance. The information technology knowledge is significant at the $90 \%$ level of confidence with 0.242 coefficient beta. IT operations are also significant at the $90 \%$ level of confidence with 0.255 coefficient beta. The information technology infrastructures are significant at the level of $95 \%$ confidence interval with the 0.296 coefficient beta. The organizational performance also has a positive influence on the financial performance of firms at the $99 \%$ confidence interval with 0.419 coefficient beta. The presence of all causal paths indicates the importance of a mediator between IT competency and the financial performance of firms. Therefore, the proposed mediation mechanism has the statistical strength to examine the indirect effect. In the second phase, we measured the specific indirect effect followed by Baron and Kenny (1986). Results show that there is a significant influence on organizational performance as a mediator between IT competency (IT knowledge, IT operation, and IT infrastructure) and the financial performance of firms. Table 4 indicates that IT knowledge positively influences the financial performance of firms through organizational performance at the $95 \%$ level of confidence. IT infrastructure is also positively affecting the financial performance via an organizational performance at the $99 \%$ confidence interval. Further, IT operation also positively impact on financial performance in relation to organizational performance but at the $90 \%$ level of confidence.

Table 4

Hypotheses Results

\begin{tabular}{llllllll}
\hline & $\begin{array}{l}\text { Independent } \\
\text { Variable }\end{array}$ & $\begin{array}{l}\text { Dependent } \\
\text { Variable }\end{array}$ & $\begin{array}{l}\text { Path } \\
\text { Coefficient }\end{array}$ & $\begin{array}{l}\text { t- } \\
\text { statistics }\end{array}$ & S.E & $\begin{array}{l}\text { P- } \\
\text { Value }\end{array}$ & Result \\
\hline H1a & IT-Knowledge & OP & 0.242 & 1.95 & 0.12 & $0.08^{*}$ & Supported \\
H1b & IT-Operations & OP & 0.255 & 2.13 & 0.12 & $0.09^{*}$ & Supported \\
H1c & IT- & OP & 0.296 & 2.66 & 0.11 & $0.03^{* *}$ & Supported \\
& Infrastructure & & & & & & \\
H2 & OP & FP & 0.419 & 3.79 & 0.11 & $0.00 * * *$ & Supported \\
H3a & IT-Knowledge & FP & 0.171 & 1.92 & 0.09 & $0.04 * *$ & Supported \\
H3b & IT-Operations & FP & 0.113 & 2.46 & 0.05 & $0.09 *$ & Supported \\
H3c & IT- & FP & 0.181 & 6.50 & 0.03 & $0.00^{* * *}$ & Supported \\
& Infrastructure & & & & & & \\
\hline
\end{tabular}

Note: $\mathrm{H} 3 \mathrm{a}, \mathrm{b}, \mathrm{c}$ represents the indirect results, $\mathrm{S} . \mathrm{E}=$ standard Error, $\mathrm{OP}=$ Organizational Performance, $\mathrm{FP}=$ Financial Performance, *represents $90 \%$ level of confidence, $* *$ represents 95 levels of confidence, $* * * 99 \%$ level of confidence 


\section{Discussion and Conclusion}

The main objective of this research was to develop and examine a model of the effect of IT competency on organizational performance and financial performance. To achieve our aim, we develop a single mediation model where three relationships were hypothesized. The finding of the research approved the existence of the mediation process. All three hypotheses were accepted but at a different level of confidence. Without the presence of mediation, the direct relationship between IT competencies (IT knowledge, IT operation, and IT infrastructure) and the financial performance except for IT knowledge all is insignificant. While testing the model by including the organizational performance as a mediator between IT competency and financial performance. The direct causal relationship between all the variables is significant. Therefore, it looks to have a positive indirect influence on IT competency and financial performance. In simple words, good organizational performance increases the positive effect of IT competency on financial performance. Similar to Shin (2006) this study also identifies the positive relation between IT competency and organizational performance. This result implies that top management supports the new technologies to create new product launching, innovation, customer relations to maintain their market value to earn higher financial benefit.

Organizational performance is the central point that ties the relationship between a firm and a customer. A positive significant effect of organizational performance on financial performance indicates a sufficient amount of market information such as competitors' current financial position, their unique points, their strength, and weaknesses that might be a tool for ensuring higher financial performance. Therefore, the role of organizational performance as a mediator strengthens the IT competency and finally improves the financial performance of the firm. This study considers organizational performance as a mediator to measure financial performance with perceptual antecedents of IT competency. Results depict that market indicators play a crucial to enhance financial performance and maintaining sustainability. Therefore, top management needs to focus on relevant market indicators rather than more focus on IT investment because such market indicators strengthen the performance. At a broader level, this study strengthens the IT theory (IT competency model) by introducing the unique process through which IT components influence financial performance. It is recommended that enterprises use an effective management information system that manages all the information. Effective computer use manages the client and competitor information that is helpful in the future to retrieve information for achieving a competitive advantage. Collected information is used to analyze their customer preference that helps to research and development department for the future innovation process. The firm should improve their technical staff that effectively handles the IT infrastructure. Furth more, the enterprise should use up-to-date professional software to manage the information.

\subsection{Limitation, Future Direction, and Managerial Implications}

One of the limits of this study was that the sample size is small. This study can be a strength to increase the large sample size. Higher authorities did not feel confident to provide confidential information such as new product development, their innovation, and their continued use of information technology in operation, and also due to time constraints sample size is small. Second, this study has targeted the enterprises. In the future, this model can be tested for SMEs. Another constraint is the moderating effect that is not considered in this study such as year of experience to use information technology and many more. Upcoming research can add a moderating effect to strengthen the finding of this research. This study used constructs that included three or four items. Therefore, this study has a measurement weakness. At last, this study measured financial performance using a survey. Future research can use secondary data to measure the financial performance that indicates the results of the financial performance.

Constructs such as IT knowledge, IT operation, and IT infrastructure all establish the initial part of the path and can be positively impacted by higher authorities and IT officers. Higher authorities strengthen the IT competencies to increase organizational performance. Also, higher authorities should look at issues concerned with organizational performance and financial performance. IT officers should implement advanced technologies and 
operations to look at the issues related to organizational performance and financial performance.IT officers create efficient ways to maintain firm sources and maximize the intrinsic value of the stock. IT officers provide new technologies and collect effective information for top management for decision making. IT competency dimensions (ITknowledge, operations, and infrastructure) are challenging in this era, especially for large enterprises. To survive in this technological era numerous management actions should be experienced. Such as (i) keeping updated their employee IT-knowledge (ii) must compare the competitors' current market value and their strength regarding IT-competencies. Therefore, this study reveals that with a better relationship between IT competencies and organizational performance, it is possible to increase financial performance. On top of the actions stated here. We suggest efforts be made to train their employee in information technology to increase their knowledge, implantation, and able to sort effective information that increases the organizational performance. In developing countries, top management should keep in mind and look at the problems that influence financial performance. The involvement of numerous constructs (IT-knowledge, IT operation, and IT infrastructure and organizational performance) may be influenced differently by a different culture to financial performance. Therefore, a future comparison research model on these constructs can develop a better understanding of their relational effects.

\section{References}

Baron, R. M., \& Kenny, D. A. (1986). The moderator-mediator variable distinction in social psychological research: Conceptual, strategic, and statistical considerations. Journal of personality and social psychology, 51(6), 1173-1182.

Batool, S., Gill, S. A., Javaid, S., \& Khan, A. J. (2021). Good Governance via E-Governance: Moving towards Digitalization for a Digital Economy. Review of Applied Management and Social Sciences, 4(4), 823-836. doi:https://doi.org/10.47067/ramss.v4i4.186

Bharadwaj, A. S. (2000). A resource-based perspective on information technology capability and firm performance: an empirical investigation. MIS quarterly, 24(1), 169-196. doi: https://doi.org/10.2307/3250983

Bhatti, M. A., Farhan, M., Ahmad, M. J., \& Sharif, M. N. (2019). The Impact of Social CRM Capabilities and Customer Engagement on the Firm Performance: Mediating Role of Social Media Usage. Pakistan Journal of Humanities and Social Sciences, 7(3), 313324. doi:https://doi.org/10.52131/pjhss.2019.0703.0089

Chien, F., Pantamee, A. A., Hussain, M. S., Chupradit, S., Nawaz, M. A., \& Mohsin, M. (2021). Nexus between financial innovation and bankruptcy: evidence from information, communication and technology (ict) sector. The Singapore Economic Review, 1-22.

Chin, W. W. (1998). The partial least squares approach to structural equation modeling. Modern methods for business research, 295(2), 295-336.

Davenport, T. H., De Long, D. W., \& Beers, M. C. (1998). Successful knowledge management projects. MIT Sloan Management Review, 39(2), 43-57.

Dong, J. Q., Karhade, P. P., Rai, A., \& Xu, S. X. (2021). How firms make information technology investment decisions: Toward a behavioral agency theory. Journal of Management Information Systems, 38(1), 29-58.

doi:https://doi.org/10.1080/07421222.2021.1870382

Durmuşoğlu, S. S., \& Barczak, G. (2011). The use of information technology tools in new product development phases: Analysis of effects on new product innovativeness, quality, and market performance. Industrial Marketing Management, 40(2), 321330. doi: https://doi.org/10.1016/j.indmarman.2010.08.009

Farooq, O., Payaud, M., Merunka, D., \& Valette-Florence, P. (2014). The impact of corporate social responsibility on organizational commitment: Exploring multiple mediation mechanisms. Journal of Business Ethics, 125(4), 563-580. doi:https://doi.org/10.1007/s10551-013-1928-3

Fornell, C., \& Larcker, D. F. (1981). Evaluating structural equation models with unobservable variables and measurement error. Journal of marketing research, 18(1), 39-50. doi:https://doi.org/10.1177/002224378101800104

Jensen, R. (2007). The digital provide: Information (technology), market performance, and welfare in the South Indian fisheries sector. The quarterly journal of economics, 122(3), 879-924. doi:https://doi.org/10.1162/qjec.122.3.879

Jianjun, H., Yao, Y., Hameed, J., Kamran, H. W., Nawaz, M. A., Aqdas, R., \& Patwary, A. K. (2021). The Role of Artificial and Nonartificial Intelligence in the New Product 
Success with Moderating Role of New Product Innovation: A Case of Manufacturing Companies in China. Complexity, 2021, 14.

Jud, G., Winkler, D., \& Sirmans, S. (2002). The impact of information technology on real estate licensee income. Journal of Real Estate Practice and Education, 5(1), 1-16. doi:https://doi.org/10.1080/10835547.2002.12091580

Junaid, A., Bashir, F., Nasim, I., \& Ahmad, R. (2021). Understanding Affective, Normative \& Continuance Commitment through the Lens of Training \& Development. iRASD Journal of Management, 3(2), 105-113.

Kamssu, A. J., Reithel, B. J., \& Ziegelmayer, J. L. (2003). Information technology and financial performance: The impact of being an Internet-dependent firm on stock returns. Information Systems Frontiers, 5(3), 279-288.

doi:https://doi.org/10.1023/A:1025649311259

Khan, A. J., Bhatti, M. A., Hussain, A., Ahmad, R., \& Iqbal, J. (2021). Employee Job Satisfaction in Higher Educational Institutes: A Review of Theories. Journal of South Asian Studies, 9(3), 257-266. doi:https://doi.org/10.33687/jsas.009.03.3940

Khan, A. J., Tufail, S., \& Ali, A. (2021). Factors Affecting Performance of Small \& Medium Enterprises: The Mediating Role of Knowledge Management. Pakistan Journal of Humanities \& Social Sciences, 9(2), 197-209. doi:https://doi.org/10.52131/pjhss.2021.0902.0129

Kozlenkova, I. V., Samaha, S. A., \& Palmatier, R. W. (2014). Resource-based theory in marketing. Journal of the academy of marketing science, 42(1), 1-21. doi:https://doi.org/10.1007/s11747-013-0336-7

Lai, F., Zhao, X., \& Wang, Q. (2006). The impact of information technology on the competitive advantage of logistics firms in China. Industrial Management \& Data Systems, 106(9), 1249-1271. doi:https://doi.org/10.1108/02635570610712564

Liang, T. P., You, J. J., \& Liu, C. C. (2010). A resource-based perspective on information technology and firm performance: a meta analysis. Industrial Management \& Data Systems, 110(8), 1138-1158. doi:https://doi.org/10.1108/02635571011077807

Marsdenia, M. (2017). Organizational Learning as Intervening Variable on Association of It Competence to Performance of Public Sector Entities: An Empirical Study at Simda of Bogor Local Government. Paper presented at the The 3rd PIABC (Parahyangan International Accounting and Business Conference.

Mitcham, C., \& Mackey, R. (1983). Philosophy and technology (Vol. 80). New York: Simon and Schuster.

Newsted, P. R., Huff, S. L., \& Munro, M. C. (1998). Survey instruments in information systems. MIS quarterly, 22(4), 553-554.

Newsted, P. R., Todd, P., \& Zmud, R. (1997). Measurement issues in the study of human factors in Management Information Systems. Chapter, 16, 211-242.

Noshad, M., Amjad, M., Shafiq, M. N., \& Gillani, S. (2019). Performance and Obstacles of SMEs: An Empirical Evidence from BRICS Countries. iRASD Journal of Economics, 1(2), 113-131. doi:https://doi.org/10.52131/joe.2019.0101.0010

Palacios-Marqués, D., Soto-Acosta, P., \& Merigó, J. M. (2015). Analyzing the effects of technological, organizational and competition factors on Web knowledge exchange in SMEs. Telematics and Informatics, 32(1), 23-32. doi:https://doi.org/10.1016/j.tele.2014.08.003

Peppard, J., Lambert, R., \& Edwards, C. (2000). Whose job is it anyway?: organizational information competencies for value creation. Information Systems Journal, 10(4), 291-322.

Pérez-López, S., \& Alegre, J. (2012). Information technology competency, knowledge processes and firm performance. Industrial Management \& Data Systems.

Powell, T. C., \& Dent-Micallef, A. (1997). Information technology as competitive advantage: The role of human, business, and technology resources. Strategic management journal, 18(5), 375-405.

Rasool, Z., Asghar, R., Gill, S. A., \& Khan, A. J. (2021). The Historical Role of Work Social Support, Corporate Social Responsibility (CSR) and Innovation Capabilities. PERENNIAL JOURNAL OF HISTORY, 2(2), 331-352.

Sadeghimanesh, M., \& Samadi, A. (2014). The effect of IT (Information Technology) on financial performance of the banks listed in Tehran Stock Exchange. European Online Journal of Natural and Social Sciences: Proceedings, 2(3), 2911-2919.

Shair, F., Shaorong, S., Kamran, H. W., Hussain, M. S., Nawaz, M. A., \& Nguyen, V. C. (2021). Assessing the efficiency and total factor productivity growth of the banking 
industry: do environmental concerns matters? Environmental Science and Pollution Research, 28(16), 20822-20838.

Shin, N. (2006). The impact of information technology on the financial performance of diversified firms. Decision Support Systems, 41(4), 698-707. doi:https://doi.org/10.1016/j.dss.2004.10.003

Slater, S. F., \& Narver, J. C. (1995). Market orientation and the learning organization. Journal of marketing, 59(3), 63-74. doi:https://doi.org/10.1177/002224299505900306

Soto-Acosta, P., Popa, S., \& Martinez-Conesa, I. (2018). Information technology, knowledge management and environmental dynamism as drivers of innovation ambidexterity: a study in SMEs. Journal of Knowledge Management, 22(4), 824-849. doi:https://doi.org/10.1108/JKM-10-2017-0448

Tam, K. Y. (1998). The impact of information technology investments on firm performance and evaluation: evidence from newly industrialized economies. Information Systems Research, 9(1), 85-98. doi:https://doi.org/10.1287/isre.9.1.85

Tatikonda, M. V., \& Montoya-Weiss, M. M. (2001). Integrating operations and marketing perspectives of product innovation: The influence of organizational process factors and capabilities on development performance. Management science, 47(1), 151-172. doi:https://doi.org/10.1287/mnsc.47.1.151.10669

Tippins, M. J., \& Sohi, R. S. (2003). IT competency and firm performance: is organizational learning a missing link? Strategic management journal, 24(8), 745-761. doi:https://doi.org/10.1002/smj. 337

Whitten, G. D., Ellis, T. S., \& Casey, K. M. (2002). The impact of information technology outsourcing on firm profitability measures. Journal of International Information Management, 11(2), 2.

Wu, S. P.-J., Straub, D. W., \& Liang, T.-P. (2015). How information technology governance mechanisms and strategic alignment influence organizational performance. MIS quarterly, 39(2), 497-518.

Zack, M., McKeen, J., \& Singh, S. (2009). Knowledge management and organizational performance: an exploratory analysis. Journal of Knowledge Management, 13(6), 392-409. doi: https://doi.org/10.1108/13673270910997088 